Check for updates

Cite this: Chem. Sci., 2017, 8, 5585

\title{
A flow cytometry assay to quantify intercellular exchange of membrane components $\dagger$
}

\author{
Dimitrios Poulcharidis, (D) ab Kimberley Belfor, ${ }^{a}$ Alexander Kros (iD) ${ }^{* b}$ and Sander I. van \\ Kasteren (iD)*a
}

Received 18th January 2017

Accepted 20th May 2017

DOI: $10.1039 / \mathrm{c} 7 \mathrm{sc00260b}$

rsc.li/chemical-science

\begin{abstract}
Membrane-compound exchange is vital for cell-to-cell communication, yet quantification of this process is difficult. Here we present a method using flow cytometry in combination with bioorthogonal and fluorescent labelling techniques to quantify the amount of exchange of cholesterol and sialylated compounds between cells. We demonstrate that direct cell-cell contact is the likely mechanism of sterol-exchange and show that by manipulating the contact time between cells using complementary coiled-coil peptides results in an enhanced exchange rate of membrane components between cells.
\end{abstract}

\section{Introduction}

The ability of cells to communicate with one another is one of the most important characteristics of eukaryotic and prokaryotic cells. ${ }^{1,2}$ Some of this communication occurs by exchange of soluble cellular components between cells, such as peptides, larger proteins, individual amino acids and nucleotides; ${ }^{2}$ by exosome secretion ${ }^{3}$ or through direct exchange of membrane components. ${ }^{4}$ This direct exchange of cellular components between neighbouring eukaryotic cells remains poorly characterized and its involvement in cell-cell communication between neighbouring cells requires further study. ${ }^{5}$

Many cell wall components are not under direct genetic control. For example, in model systems, radiolabelled or fluorescently-labelled cholesterol has been shown to exchange intracellularly between organelles, ${ }^{6}$ liposomes $^{7}$ as well as between serum and erythrocytes. ${ }^{8}$ The rate of lipid exchange in liposomes varies depending on the solubility, the acyl-chain, the length of the fatty acid and the hydrophobicity. ${ }^{7,9,10}$ For example most phosphatidylcholines (PtdCho) in cells with 16 or more carbons acyl chains, have a transfer half-time of 83 h..$^{9-11}$ On the other hand, 25-hydroxycholesterols $(25 \mathrm{OH})$ is more hydrophilic than cholesterol and therefore exchanges more rapidly, ${ }^{\mathbf{9}, 12,13}$ whereas cholesteryl oleate is more hydrophobic than cholesterol and exchanges more slowly. ${ }^{9}$

Exchange of cholesterol was also recently reported between host cells and bacteria i.e. Borrelia burgdorferi to be a very

${ }^{a}$ Division of Bio-organic Synthesis, Leiden Institute of Chemistry, Gorlaeus Laboratories, Leiden University, Leiden, The Netherlands. E-mail: s.i.van.kasteren@ chem.leidenuniv.nl

${ }^{b}$ Division of Supramolecular and Biomaterials Chemistry, Leiden Institute of Chemistry, Leiden University, Einsteinweg 55, 2333 CC Leiden, The Netherlands. E-mail:a.kros@chem.leidenuniv.nl

$\dagger$ Electronic supplementary information (ESI) available. See DOI: 10.1039/c7sc00260b important process in the pathogenesis or infectivity of pathogens. ${ }^{\mathbf{1 4}}$

Aside from these examples of cholesterol exchange, the study of membrane component exchange is relatively underexplored, ${ }^{\mathbf{1 5}, 16}$ especially in mammalian cell systems. The dynamics and kinetics of membrane compound exchange-critically impacts several important biological functions in cells including signal transduction, cell-cell recognition, energy production and conversion, cell adhesion and foreign molecule identification. ${ }^{17,18}$

Here we present an adaptable strategy utilising flow cytometry in which we use labelled membrane components to quantify their exchange rates (Scheme 1) between mammalian cells in co-culture, quantify the interactions between glycans and membrane lipids and understand the exchange mechanism. We use this approach to study the exchange of fluorescently labelled cholesterol, ${ }^{19}$ alkyne-modified cholesterol, ${ }^{20}$ and azide-

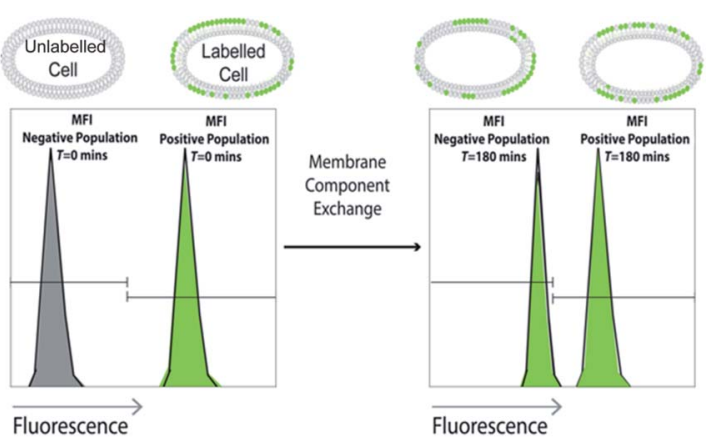

Scheme 1 Schematic overview of the approach: cell lines are treated with fluorescently labelled sterol and/or glycan and co-cultured with analogous untreated cells. Analysis by flow cytometry over time shows the rate of exchange of the fluorescent membrane component to the non-fluorescent population as a shift in Mean Fluorescent Intensity (MFI). 
modified sialic acids. ${ }^{21}$ The latter two are visualised in a 2-step bioorthogonal method..$^{22,23}$ Using our approach we show that the rate of sterol exchange is cell-line dependent and that the rate of sialic acid-containing component exchange is significantly slower than that of the sterolic lipids. Finally, we show that a non-exchanging cell line can be forced to exchange both sterols when forced into prolonged close proximity using complementary coiled-coils, ${ }^{24,25}$ suggesting that lipid exchange mediated by direct contact is the dominant mechanism of sterol-exchange in these cells.

\section{Results and discussion}

\section{Cell-type dependent lipid exchange}

Our initial aim was to develop a broadly deployable assay that would allow the facile quantification and mechanistic characterisation of the exchange of membrane components between cells by flow cytometry (Scheme 1). We first used the recently reported bodipy-modified cholesterol (1, Avanti Scheme 2), which readily inserts into eukaryotic cell membranes. ${ }^{19}$

To study whether exchange of this lipid could be observed we incubated HeLa, ${ }^{26} \mathrm{U}_{2}-\mathrm{Os},{ }^{27} \mathrm{Jurkat}^{28}{ }^{28} \mathrm{AMO}^{29}$ and B3Z-T-cells ${ }^{30}$ with 1 as described (see ESI $\dagger$ ). ${ }^{19}$ Unlabelled cells were then mixed with labelled cells and co-cultured at $37{ }^{\circ} \mathrm{C}$ for different times. The amount of exchange of the fluorescently-labelled cholesterol over time between these two populations was then determined using flow cytometry (Fig. 1 and S1 $\dagger \dagger$ ). In this assay, the rate of exchange of $\mathbf{1}$ was shown to vary significantly between the different cell lines: after $3 \mathrm{~h}$ HeLa and U2-Os had

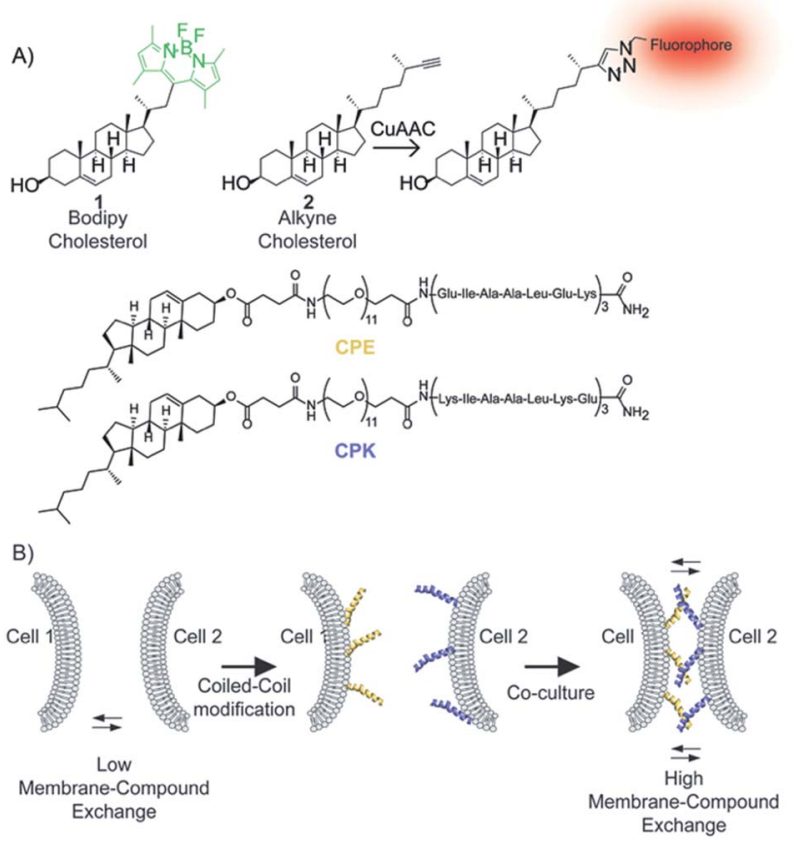

Scheme 2 (A) Structures of bodipy-cholesterol (bdp-Ch, 1), alkynecholesterol (Alk-Ch, 2), cholesterol modified $E_{3}$ (CPE) and $K_{3}$ (CPK) peptides. (B) Schematic representation of coiled-coil formation and its use to prolong cell-cell contact thus enhancing membrane compound exchange.

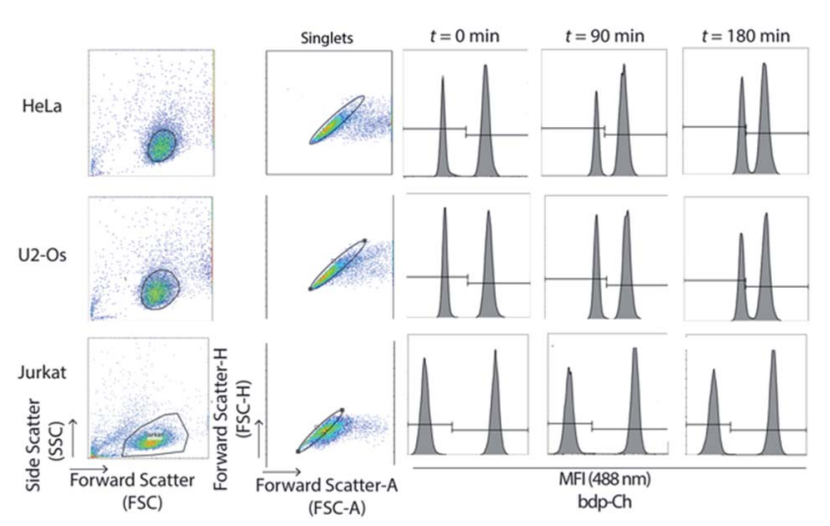

Fig. 1 The flow cytometry assay indicates cholesterol exchange between live HeLa and U2-Os cells whereas no exchange occurs between Jurkat cells. Cells were treated with $5 \mu \mathrm{M}$ bdp-cholesterol (1) for $18 \mathrm{~h}$. Labelled and unlabelled live cells were co-cultured and flow cytometry was completed. The cell population was gated based on FSC-A vs. SSC-A (cell doublets were gated out using FSC-A vs. FSC-H) and histograms of mixed cells $t=0,90$ and $180 \mathrm{~min}$ are shown for each cell line with MFI (Mean Fluorescent Intensity) gated accordingly.

exchanged $4.5 \pm 0.17 \%$ and $4.4 \pm 0.05 \%$ of 1 respectively. Jurkat, AMO and B3Z cells on the other hand had exchanged $<1 \%(0.9 \pm 0.23 \%, 0.4 \pm 0.03 \%$ and $0.6 \pm 0.12 \%$ respectively $)$ (Fig. 2A and B). No exchange between suspension cell lines (which have limited cell-cell contact) was observed, which led us to hypothesize that cell-cell contact might be the driver for membrane lipid exchange. The rate of exchange (\% exchange, $\Delta$ MFI, eqn (1)) was normalised to live cells based on scatter plots and cellular fluorescence. The $\Delta$ MFI was calculated as the amount of fluorescent intensity the unlabelled (negative) cells gained at time $t=180 \mathrm{~min}$ of co-culture with labelled (positive)
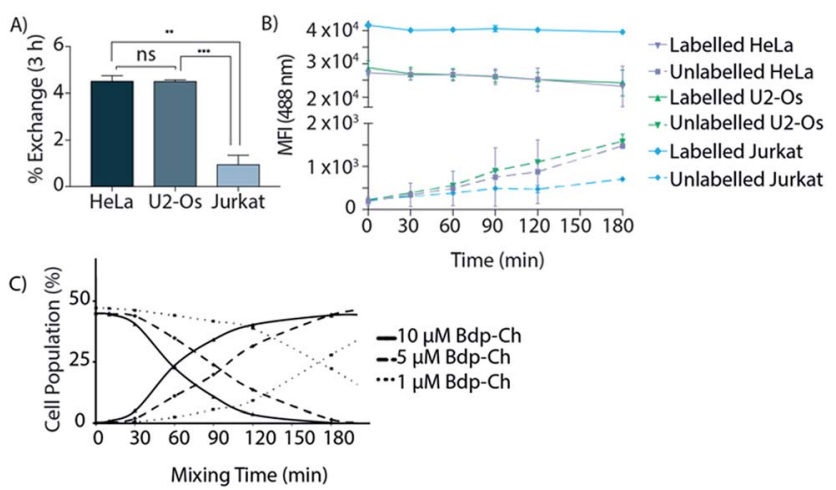

Fig. 2 (A) The \% exchange or $\triangle M F I$ of the fluorescent signal exchange after $3 \mathrm{~h}$ co-culturing was calculated using $\Delta \mathrm{MFI}=\left(\mathrm{MFI}_{\text {negative }}(t=180 \mathrm{~min})-\right.$

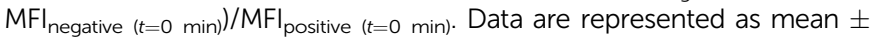
SD. Error bars SD; $* p<0.05 ; * * p<0.01 ; * * * p<0.001$; ns = not significant; unpaired t-tests. (B) Mean Fluorescent Intensity (MFI) of labelled and unlabelled cells over varied co-culturing time periods. Data are represented as mean \pm SD. Error bars SD. (C) Cholesterol exchange is concentration dependent. In live HeLa cells, the amount of co-culturing time for $25 \%$ of the unlabelled population to get labelled varies significantly under different lipid concentrations. Cells were treated with $1 \mu \mathrm{M}$, $5 \mu \mathrm{M}$ or $10 \mu \mathrm{M}$ bdp-Ch (1) for $18 \mathrm{~h}$ prior to co-culturing with unlabelled live cells. 
cells in correlation with the total fluorescent intensity (the initial fluorescently labelled cell population) (see eqn (1)).

$$
\Delta \mathrm{MFI}=\frac{\mathrm{MFI}_{\text {negative }(t=180 \mathrm{~min})}-\mathrm{MFI}_{\text {negative }(t=0 \mathrm{~min})}}{\mathrm{MFI}_{\text {positive }}(t=0 \mathrm{~min})}
$$

here, flow cytometry was used to determine the differences in cholesterol exchange between live HeLa cells as a function of lipid concentrations. Cells were treated with bodipy-modified cholesterol (bdp-Ch, 1; $1 \mu \mathrm{M}, 5 \mu \mathrm{M}$ and $10 \mu \mathrm{M}$ ) for $18 \mathrm{~h}$ before mixing with unlabelled live cells.

Upon flow cytometry analysis, the cell populations were gated based on forward scatter-Area (FSA-A) and side scatterArea (SSC-A) characteristics (cell doublets were gated out using FSC-A vs. FSC-H). An increase in the percentage of a newlabelled cell population and a decrease in the number of unlabelled cells was observed, indicating that rate of exchange of cholesterol 1 is concentration dependent (Fig. 2C).

In order to study that the observed exchange rates were not due to the fluorescent label, unmodified bodipy- 488 was used as a control and as expected did not exchange (Fig. S2 $\dagger$ ), showing that the sterol moiety is essential for the exchange reaction.

Altering the ratio of labelled $v s$. unlabelled cells $(1: 1,1: 5$, $1: 10)$ and vice versa, or increasing the culture volume, also affected the rate of exchange (Fig. S3†) showing that close contact is necessary for the membrane-compound exchange. It was found that the higher the fraction of labelled cells, the faster the exchange: $1: 1$ ratios exchanged 19 times faster than a $1: 10$ ratio of labelled $v s$. unlabelled cells $(3.9 \pm 0.5 \% v s .0 .2 \pm$ $0.05 \%$; Fig. S3†). In order to exclude the fact that the observed cholesterol exchange was due to endocytosis of cell debris, passively uptake from dead cells or exosomes, but due to a livecell dependent process, we performed a series of different control experiments. Cell viability in the co-culture experiments was assessed prior to flow cytometry using the (live-cell impermeable) dye propidium iodide (PI). Cell death in all co-culture experiments was equal to controls and was always $<2 \%$ (Fig. S4B and $\mathrm{C}^{\dagger}$ ).

In order to exclude the fact that the observed cholesterol exchange was due to endocytosis of cell debris from this $2 \%$ of dead cells, unlabelled cells were co-cultured with the lysate of cells labelled with $\mathbf{1}$. In this system, there was not any lipid uptake or fluorescent labelling after $3 \mathrm{~h}$ (Fig. S4A $\dagger$ ) at a lysate concentration representing of $5 \%$ dead cells.

In order to determine whether exchange of lipids was energydependent, we used sodium azide, or low temperature as wellestablished metabolic inhibitors of ATP-production. ${ }^{31-33}$ Upon ATP depletion with sodium azide or low-temperature, membrane lipid exchange was minimised or abolished respectively indicating that the cholesterol exchange is energy dependent (Fig. S5†).

Chemical fixation (to inactivate all biochemistry in the cell $^{34,35}$ ) prior to mixing abolished all exchange (Fig. S1B $\dagger$ ) indicating that the lipid exchange is a live-cell dependent process.

To study whether the mechanism of exchange was based on the exchange of exosomes, the exchange of free $\mathbf{1}$ or cell-cell contact, we spatially separated the unlabelled and labelled populations in a trans-well assay (Fig. S6†). ${ }^{36}$ All sterol exchange was abolished, even when large-pore $(0.4 \mu \mathrm{m})$ membranes were used (through which exosomes can pass, but cells cannot ${ }^{37}$ ), indicating that cell-cell contact is most likely responsible for the exchange of $\mathbf{1}$. The absence of any incorporation of $\mathbf{1}$ in unlabelled cells after a supernatant transfer from a labelled population (Fig. S7 $\dagger$ ) strongly supports the hypothesis that cellcell contact is the main method of exchange of cholesterol in this system.

\section{Coiled-coil complementation enhanced lipid exchange}

To further investigate that close contact between cells is important for lipid transfer, we tested whether forcing the cells into prolonged close proximity would enhance the exchange rate. For this a supramolecular approach was chosen, in which a pair of complementary lipidated coiled-coil (CC) peptide was introduced ${ }^{24,25}$ to force cells in close proximity in a non-covalent manner (Scheme 2). Coiled-coil-forming peptides $\mathrm{E}$ $\left[(\text { EIAALEK })_{3}\right]$ and $\mathrm{K}\left[(\mathrm{KIAALKE})_{3}\right]$ conjugated via a poly(ethylene glycol) ${ }_{12}$ spacer with a cholesterol moiety (denoted CPE or CPK respectively) have been reported to insert spontaneously into cell membranes, ${ }^{38-43}$ and were used here lipid exchange study.

To study the effect of forced proximity on cholesterol exchange we used lymphocytic Jurkat cells as it showed the lowest exchange rate (Fig. 2A). The cells were labelled overnight with 1 and after washing were incubated with $5 \mu \mathrm{M}$ cholesterolCPE. In parallel, unlabelled cells were treated with $5 \mu \mathrm{M} \mathrm{CPK}$. Next, the CPE- and CPK-modified Jurkat cells were mixed and the rate of exchange of $\mathbf{1}$ was determined. Flow cytometry results indicate that upon coiled-coil formation between CPEand CPK-modified cells, membrane-cholesterol exchange was enhanced 3-fold (from $1.0 \pm 0.18 \%$ to $3.3 \pm 0.35 \%$ ) compared to CC peptide untreated cells. The results are suggestive of the exchange rate of 1 being enhanced by forced membrane contact (Fig. 3C and S8B $\dagger$ ). Confocal microscopy after $3 \mathrm{~h}$ confirmed that upon coiled-coil formation cells were coming in close proximity (Fig. S8A†).

\section{Glycan exchange between live mammalian cells}

Many membrane components are not amenable to selective fluorophore labelling and the bulky nature of such groups can affect the biological properties of the parent molecule. After establishing the exchange rate of fluorophore modified cholesterol 1 between different cell types and manipulating these rates of exchange through forcing cell-cell contacts, we wanted to combine the cytometry analysis with the detection of bioorthogonal groups in a 2-step approach ${ }^{44}$ to monitor the exchange of other membrane components.

Bioorthogonal chemistry can be used to visualise nongenetically templated biomolecules in cells by means of incorporating a small biologically inert chemical group into a biomolecule-class of choice and visualising these at the end of an experiment using tag-selective ligation chemistry. ${ }^{22,23}$ The main advantage of this approach is that the small and stable bioorthogonal groups can be incorporated into non-templated molecules and then can hijack the biosynthetic pathways of 
A)
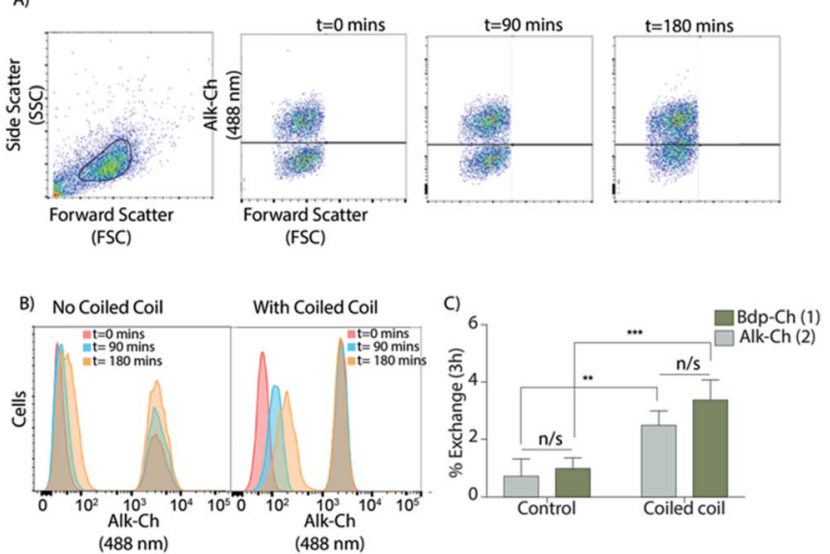

Fig. 3 (A) Forcing cells in close proximity using lipidated coiled-coil (CC) peptides enhances sterol exchange. The first dot-plot shows the gated cell population followed by three dot-plots showing the coalescence of the labelled and unlabelled cells using Alk-Ch (2) at $t=0$, 90, and 180 min. (B) Histograms of Jurkat cells over different coculturing times using alk-Ch (2, Avanti) with and without coiled-coil peptides. (C) Exchange rates of 1 and 2 in Jurkat cells after $3 \mathrm{~h}$ coculturing in the presence or absence of $\mathrm{CC}$ peptides. Both 1 and 2 show similar exchange rates between CC- and non-CC-labelled cell populations. Data are represented as mean \pm SD. Error bars SD; ${ }^{*} p<$ $0.05 ; * * p<0.01 ; * * *<0.001$; unpaired $t$-tests.

these molecules. This approach has been used extensively to label many different cell biomolecules, such as glycans, lipids and nucleotides. ${ }^{45,46}$ To determine whether a 2-step bioorthogonal approach could be used to measure exchange kinetics, we first validated the approach using the recently reported alkyne-modified cholesterol (2, Avanti). ${ }^{20}$ In a coiled-coilenhanced exchange experiment in non-adherent Jurkat cells, a comparable 2.5-fold increase in the exchange rate with and without coiled-coil treatment was observed (from $0.7 \pm 0.30 \%$ without CC to $2.5 \pm 0.25 \%$ with CC after 3 h; Fig. 3 and S9†). For this experiment, live-cell compatible variants of the coppercatalyzed azide-alkyne cycloaddition (CuAAC) were initially used. $^{47}$

We initially optimised ccHc conditions using a populationbased viability assays (WST-1 and 7-AAD assays). Based on previously reported protocols ${ }^{48-50}$ using lower copper concentrations in combination with chelating ligands (TTMA, THPTA, BTTAA etc.) toxicity was minimized (Fig. S11 $\dagger$ ). However, under the CuAAC-conditions used, the cells displayed aberrant morphology indicating stress or early cell death ${ }^{52}$ (Fig. S10 $\dagger$ ), leading us to abandon the live cell CuAAC-attempts in favour of protocol consisting of a fixation step prior to performing the CuAAC reaction. ${ }^{35,51}$

Having established the suitability (and limitations) of a bioorthogonal approach to detect cholesterol exchange, we used a similar approach to determine whether we could also monitor the exchange of another integral membrane component: sialoglycoproteins and sialoglycolipids.

These vital membrane components have been associated with cell-cell communication, metastatic behaviour, human disease and cell recognition. ${ }^{53}$ We first labelled HeLa-cells using

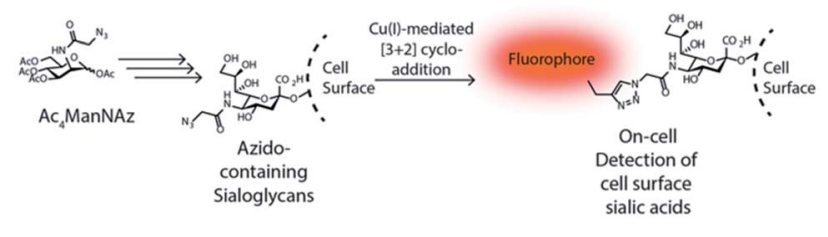

B)
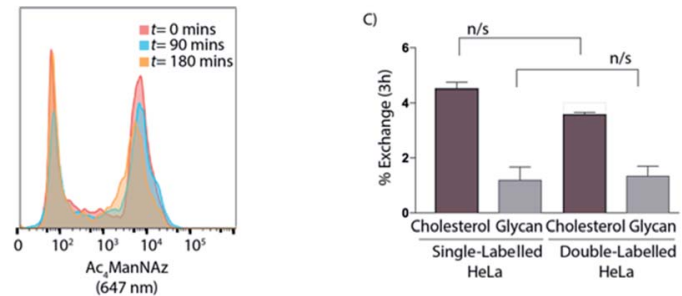

Fig. 4 (A) Schematic representation of cell surface glycan labelling. (B) Flow cytometry overlay histograms upon different times show no enhancement of glycolipid exchange between jurkat cells after coiledcoil formation; jurkat cells were treated with $\mathrm{Ac}_{4} \mathrm{ManNAz}$ and $\mathrm{CPE}$ cocultured with untreated cells with CPK and labelled with CuAAC. (C) $\Delta \mathrm{MFI}\left[\Delta \mathrm{MFI}=\left(\mathrm{MFI}_{\text {negative }}(180 \mathrm{~min})-\mathrm{MFI}_{\text {negative }}(0 \mathrm{~min})\right) / \mathrm{MFI}_{\text {positive }}(0 \mathrm{~min})\right]$ expression of exchange after $3 \mathrm{~h}$ between sterol and glycan in singleand double-labelled co-culture experiments; data show lipid exchange independently of the glycan exchange. Data are represented as mean $\pm \mathrm{SD}$. Error bars SD; $\mathrm{n} / \mathrm{s} p>0.05$; unpaired $t$-tests.

a bioorthogonal analogue of the metabolic precursor of sialic acid, per-O-acetylated $\mathrm{N}$-2-azidoacetylmannosamine $\left(\mathrm{Ac}_{4}{ }^{-}\right.$ ManNAz), ${ }^{21}$ which is converted to sialic acid in cellulo and transferred to nascent galactose-terminated glycans in the trans-Golgi network (Fig. 4A). Here, HeLa cells were treated as described $^{\mathbf{4 9}, 54-56}$ with $50 \mu \mathrm{M} \mathrm{Ac}_{4} \mathrm{ManNAz}$ for $72 \mathrm{~h}$ prior to mixing and co-culturing with untreated HeLa cells. Flow cytometry after paraformaldehyde fixation (2\%) showed that the rate of exchange of the sialoglycome was significantly slower $(0.98 \pm$ $0.40 \%$ after $3 \mathrm{~h}$ ) compared to cholesterol exchange (Fig. $4 \mathrm{~B}$ and $\mathrm{C}$ and $\mathrm{S} 12 \dagger)$.

This lack of exchange was not due to the $\mathrm{Ac}_{4} \mathrm{ManNAz}^{-}$ labelling, as the exchange of $\mathbf{1}$ in cells labelled with both $\mathrm{Ac}_{4^{-}}$ ManNAz and 1 was unaffected (Fig. 4C). We can only speculate about the biological significance of the absence of exchange: the observed slower exchange of glycans between cells may reflect reduced freedom of movement of these larger sialoglycolipids in the cell membrane; or their specific function in cell adhesion. ${ }^{57-59}$

\section{Conclusions}

In conclusion, this study demonstrates that different mammalian cells exchange membrane components in a time- and celltype dependent manner. This exchange appears to be due to cell-cell contacts and can be enhanced when cells are forced in close proximity. The exchange of sialylated membrane components appears to be significantly slower compared to sterols, indicating the presence of differential control mechanisms of exchange for these components. Isotope-labelled cholesterol in combination with mass spectroscopy and targeted metabolomics could be used in later stage for validation of the 
aforementioned technique. These experiments could be used to study the exchange of other lipids as well, such as inflammatory mediators ${ }^{60,61}$ and mediators of neuronal signaling ${ }^{62,63}$ as these have been shown to be amenable to bioorthogonal or fluorescent modification. ${ }^{64}$ This will likely help to improve understanding of the role of these compounds in cell-to-cell communication, cell interactions and disease development.

\section{Acknowledgements}

SIvK was funded by an ERC Starting Grant (Number 639005). SIvK, and AK were also funded by the Netherlands Scientific Council (NWO) via a VICI grant (724.014.001).

\section{References}

1 C. M. Waters and B. L. Bassler, Annu. Rev. Cell Dev. Biol., 2005, 21, 319-346.

2 P. H. Raven, G. B. Johnson, J. B. Losos and S. R. Singer, in Biology, 2004.

3 R. C. Lai, F. Arslan, M. M. Lee, N. S. K. Sze, A. Choo, T. S. Chen, M. Salto-Tellez, L. Timmers, C. N. Lee, R. M. El Oakley, G. Pasterkamp, D. P. V de Kleijn and S. K. Lim, Stem Cell Res., 2010, 4, 214-222.

4 G. Turturici, R. Tinnirello, G. Sconzo and F. Geraci, Am. J. Physiol.: Cell Physiol., 2014, 306, C621-C633.

5 X. Niu, K. Gupta, J. T. Yang, M. J. Shamblott and A. Levchenko, J. Cell Sci., 2009, 122, 600-610.

6 E. Ikonen, Nat. Rev. Mol. Cell Biol., 2008, 9, 125-138.

7 K. A. Solanko, M. Modzel, L. M. Solanko and D. Wüstner, Lipid Insights, 2015, 8, 95-114.

8 Y. Lange, C. M. Cohen and M. J. Poznansky, Proc. Natl. Acad. Sci. U. S. A., 1977, 74, 1538-1542.

9 S. Lev, Nat. Rev. Mol. Cell Biol., 2010, 11, 739-750.

10 J. E. Ferrell Jr, K. J. Lee and W. H. Huestis, Biochemistry, 1985, 24, 2857-2864.

11 L. R. McLean and M. C. Phillips, Biochemistry, 1984, 23, 4624-4630.

12 M. C. Phillips, W. J. Johnson and G. H. Rothblat, Biochemistry, 1987, 906, 223-276.

13 W. A. Prinz, Prog. Lipid Res., 2007, 46, 297-314.

14 J. T. Crowley, A. M. Toledo, T. J. LaRocca, J. L. Coleman, E. London and J. L. Benach, PLoS Pathog., 2013, 9, e1003109.

15 M. Mittelbrunn and F. Sánchez-Madrid, Nat. Rev. Mol. Cell Biol., 2012, 13, 328-335.

16 A. M. Skinner, S. L. O'Neil and P. Kurre, PLoS One, 2009, 4, e6219.

17 M. A. Deverall, E. Gindl, E.-K. Sinner, H. Besir, J. Ruehe, M. J. Saxton and C. A. Naumann, Biophys. J., 2005, 88, 1875-1886.

18 S. Ly, F. Bourguet, N. O. Fischer, E. Y. Lau, M. A. Coleman and T. A. Laurence, Biophys. J., 2014, 106, L05-L08.

19 M. Hölttä-Vuori, R. L. Uronen, J. Repakova, E. Salonen, I. Vattulainen, P. Panula, Z. Li, R. Bittman and E. Ikonen, Traffic, 2008, 9, 1839-1849.
20 K. Hofmann, C. Thiele, H.-F. Schött, A. Gaebler, M. Schoene, Y. Kiver, S. Friedrichs, D. Lütjohann and L. Kuerschner, J. Lipid Res., 2014, 55, 583-591.

21 E. Saxon and C. R. Bertozzi, Science, 2000, 287, 2007-2010.

22 E. M. Sletten and C. R. Bertozzi, Angew. Chem., Int. Ed., 2009, 48, 6974-6998.

23 C. Besanceney-Webler, H. Jiang, T. Zheng, L. Feng, D. Soriano del Amo, W. Wang, L. M. Klivansky, F. L. Marlow, Y. Liu and P. Wu, Angew. Chem., Int. Ed. Engl., 2011, 50, 8051-8056.

24 H. Robson Marsden and A. Kros, Angew. Chem., Int. Ed. Engl., 2010, 49, 2988-3005.

25 B. D. N. Woolfson, Adv. Protein Chem., 2005, 70, 79-112.

26 G. O. Gey, W. D. Coffman and M. T. Kubicek, Cancer Res., 1952, 12, 264-265.

27 J. Ponten and E. Saksela, Int. J. Cancer, 1967, 2, 434-447.

28 U. Schneider, H. U. Schwenk and G. Bornkamm, Int. J. Cancer, 1977, 19, 621-626.

29 S. Shimizu, T. Takiguchi, M. Fukutoku, R. Yoshioka, Y. Hirose, S. Fukuhara, H. Ohno, Y. Isobe and S. Konda, Leukemia, 1993, 7, 274-280.

30 J. Karttunen and N. Shastri, Proc. Natl. Acad. Sci. U. S. A., 1991, 88, 3972-3976.

31 V. P. Torchilin, R. Rammohan, V. Weissig and T. S. Levchenko, Proc. Natl. Acad. Sci. U. S. A., 2001, 98, 8786-8791.

32 M. Tsubaki, Biochemistry, 1993, 32, 174-182.

33 J. Harvey, S. C. Hardy and M. L. Ashford, Br. J. Pharmacol., 1999, 126, 51-60.

34 E. C. T. Yeung, C. Stasolla, M. J. Sumner and B. Q. Huang, in Plant Microtechniques and Protocols, Springer International Publishing, 2015, pp. 22-43.

35 H. M. Shapiro, Practical Flow Cytometry, John Wiley \& Sons, New Jersey, 4th edn, 2003.

36 J. Iqbal, K. Anwar and M. M. Hussain, J. Biol. Chem., 2003, 278, 31610-31620.

37 M. K. Herroon, E. Rajagurubandara, D. L. Rudy, A. Chalasani, A. L. Hardaway and I. Podgorski, Oncogene, 2013, 32, 1580-1593.

38 H. R. Zope, F. Versluis, A. Ordas, J. Voskuhl, H. P. Spaink and A. Kros, Angew. Chem., Int. Ed. Engl., 2013, 52, 14247-14251.

39 F. Versluis, J. Voskuhl, B. Van Kolck, H. Zope, M. Bremmer, T. Albregtse and A. Kros, J. Am. Chem. Soc., 2013, 135, 80578062.

40 L. Kong, S. H. C. Askes, S. Bonnet, A. Kros and F. Campbell, Angew. Chem., Int. Ed., 2015, 1396-1400.

41 N. Lopez Mora, A. Bahreman, H. Valkenier, H. Li, T. Sharp, D. N. Sheppard, A. kros and A. Davis, Chem. Sci., 2016, 7, 1768-1772.

42 J. Yang, A. Bahreman, G. Daudey, J. Bussmann, R. C. L. Olsthoorn and A. Kros, ACS Cent. Sci., 2016, 2, 621-630.

43 J. Yang, Y. Shimada, R. C. L. Olsthoorn, B. E. Snaar-Jagalska, H. P. Spaink and A. Kros, ACS Nano, 2016, 10, 7428-7435.

44 G. Charron, Acc. Chem. Res., 2011, 44, 699-708.

45 X. Zhang and Y. Zhang, Molecules, 2013, 18, 7145-7159. 
46 D. M. Patterson, L. A. Nazarova and J. A. Prescher, ACS Chem. Biol., 2014, 9, 592-605.

47 V. Hong, N. F. Steinmetz, M. Manchester and M. G. Finn, Bioconjugate Chem., 2010, 21, 1912-1916.

48 C. Uttamapinant, A. Tangpeerachaikul, S. Grecian, S. Clarke, U. Singh, P. Slade, K. R. Gee and A. Y. Ting, Angew. Chem., Int. Ed., 2012, 51, 5852-5856.

49 D. Soriano Del Amo, W. Wang, H. Jiang, C. Besanceney, A. C. Yan, M. Levy, Y. Liu, F. L. Marlow and P. Wu, J. Am. Chem. Soc., 2010, 132, 16893-16899.

50 C. Uttamapinant, M. I. Sanchez, D. S. Liu, J. Z. Yao and A. Y. Ting, Nat. Protoc., 2013, 8, 1620-1634.

51 L. A. Herzenberg, Nat. Immunol., 2006, 7, 681-685.

52 G. C. Salzman, S. B. Singham, R. G. Johnston and C. F. Bohren, in Flow Cytometry and Sorting, ed. M. R. Melamed, T. Lindmo and M. L. Mendelsohn, Wiley-Liss, New York, 1990, pp. 81-107.

53 N. M. Varki and A. Varki, Lab. Invest., 2007, 87, 851-857.

54 S. T. Laughlin and C. R. Bertozzi, Nat. Protoc., 2007, 2, 29302944.

55 F. R. Maxfield and D. Wüstner, Methods Cell Biol., 2012, 108, 367-393.
56 L. Yang, J. O. Nyalwidhe, S. Guo, R. R. Drake and O. J. Semmes, Mol. Cell. Proteomics, 2011, 10, M110.007294.

57 D. H. Dube and C. R. Bertozzi, Nat. Rev. Drug Discovery, 2005, 4, 477-488.

58 S. Iyer, R. M. Gaikwad, V. Subba-Rao, C. D. Woodworth and I. Sokolov, Nat. Nanotechnol., 2009, 4, 389-393.

59 H. Jiang, B. P. English, R. B. Hazan, P. Wu and B. Ovryn, Angew. Chem., Int. Ed., 2015, 54, 1765-1769.

60 B. D. Levy, C. B. Clish, B. Schmidt, K. Gronert and C. N. Serhan, Nat. Immunol., 2001, 2, 612-619.

61 M. Winkler, BJOG, 2003, 110, 118-123.

62 M. van der Stelt and V. Di Marzo, NeuroMol. Med., 2005, 7, 37-50.

63 F. A. Iannotti, V. Di Marzo and S. Petrosino, Prog. Lipid Res., 2016, 62, 107-128.

64 M. P. Baggelaar, F. J. Janssen, A. C. M. Vanesbroeck, H. Dendulk, M. Allara, S. Hoogendoorn, R. McGuire, B. I. Florea, N. Meeuwenoord, H. Vandenelst, G. A. Vandermarel, J. Brouwer, V. Dimarzo, H. S. Overkleeft and M. Vanderstelt, Angew. Chem., Int. Ed., 2013, 52, 12081-12085. 